\title{
CHRONIC GENERALIZED OEDEMA AND HYPOPROTEINAEMIA OF OBSCURE ORIGIN
}

\author{
BY \\ R. S. ILLINGWORTH and E. FINCH \\ From the Children's Hospital Unit, the United Sheffield Hospitals
}

(RECEIVED FOR PUBLICATION MAY 20, 1954)

Scattered through the literature of the world are a few case reports of chronic generalized oedema with hypoproteinaemia, not associated with defective protein intake, or with an obviously increased loss of protein, such as occurs in albuminuria. Some of these have proved to be associated with changes in the liver, and therefore presumably with protein synthesis. Some of this group, in addition, had steatorrhoea. The causes of hypoproteinaemia were well reviewed by Melnick and Cowgill (1937).

Thompson, McQuarrie and Bell (1936) described a 2-year-old girl with oedema and hypoproteinaemia, which did not respond to a high-protein diet. The total serum proteins were $3.4 \mathrm{~g}$. per $100 \mathrm{ml}$. (albumin 1.9 g., globulin 1.5 g.). The nitrogen balance was consistently positive. The fact that after transfusion the fall of the serum protein level was very gradual suggested that an abnormal destruction of protein was not the cause of the hypoproteinaemia. At necropsy she had widespread atrophy of hepatic cells, confined chiefly to the intermediate and peripheral areas of the liver lobules, the central zones being spared. They termed the condition 'primary atrophy of the liver of unknown aetiology'. This is apparently the same patient as that described in another paper (Thompson, Ziegler and McQuarrie, 1932).

Warfield (1936) described a 49-year-old woman with generalized oedema, a large liver but normal plasma proteins.

Salvesen and Boe (1937) described a 31-year-old woman with chronic oedema, ascites, large liver and normal renal function tests. There was achlorhydria. The total serum proteins were normal ( 6 to $7 \cdot 5 \mathrm{~g}$. per $100 \mathrm{ml}$.), but the albumin was reduced $(2 \cdot 8$ to $3 \cdot 3 \mathrm{~g}$. per $100 \mathrm{ml}$.). The serum globulin was 2.7 to 4.7 per $100 \mathrm{ml}$. The oedema persisted for the seven months for which she was observed.

Schick and Greenbaum (1945) described a child of 11 years old who had had recurrent oedema from the age of 12 weeks. Her mother had had oedema, possibly of nutritional origin. The girl had hypoproteinaemia (total serum proteins $3.3 \mathrm{~g}$. per $100 \mathrm{ml}$.; albumin $2.5 \mathrm{~g}$., globulin $0.8 \mathrm{~g}$. per $100 \mathrm{ml}$.). The urine, blood pressure, and renal function tests were normal. The liver function tests were not quite normal. The serum alkaline phosphatase was 27 King-Armstrong units, the hippuric acid test was borderline, and the glucose tolerance curve was flat. The gamma globulin content of the serum was greatly reduced. A high-protein diet made no difference to the oedema or to the serum protein content.

Jonsson and Lagercrantz (1950) described an 18-month-old boy with oedema, hypoproteinaemia and loose stools, but without steatorrhoea. There was no anaemia. The total serum proteins were 3.1 g. per $100 \mathrm{ml}$. Electrophoresis showed the albumin to be $30 \cdot 9 \%$, alpha globulin $12 \cdot 8 \%$, beta globulin $42 \cdot 8 \%$, gamma globulin $13 \cdot 5 \%$, fibrinogen $0.29 \%$. The thymol turbidity, Takata-Ara and alkaline phosphatase tests were normal. The amino-acid absorption curve was normal. At necropsy there was a diffuse fatty degeneration of the liver, with an interstitial fibrosis.

Binger and Keith (1937a, b) described a 62-yearold man with chronic oedema, hypoproteinaemia (total serum proteins $3.6 \mathrm{~g}$. per $100 \mathrm{ml}$., with an albumin globulin ratio of $1: 1 \cdot 6$ ), a low serum calcium and steatorrhoea. At necropsy he had interstitial hepatitis. All sections of the pancreas showed almost complete atrophy of acinous tissue. This corresponded to what Hantelmann (1931) termed 'lipomatous pseudohypertrophy of the pancreas'. Lumb and Beautyman (1952) described a similar condition in a 4-week-old baby, who presented with anaemia, oedema, steatorrhoea, hypoproteinaemia (total serum proteins $5 \mathrm{~g}$. per $100 \mathrm{ml}$., albumin 2.68 g., globulin $2.32 \mathrm{~g}$. per $100 \mathrm{ml}$.), and absence of trypsin in the stools and duodenal juice. At necropsy the glandular tissue of the pancreas was almost completely replaced by fat, 
with only a small quantity of granular material in the centre. There was a complete absence of acinar elements, which were replaced by normal adult adipose tissue. There was no increase of fibrous tissue, and the islets were normal. They termed the condition "hypoplasia of the exocrine tissue of the pancreas'.

In the cases described by both Ødegård (1948) and Jones (1949), in addition to cystic fibrosis of the pancreas, there was fatty degeneration of the liver. The former gave very few details about his two cases.

Jungmann (1922) described a man of 28 with chronic oedema and hypoproteinaemia (total serum proteins $3 \cdot 9-5.0 \mathrm{~g}$. per $100 \mathrm{ml}$.) with enlarged parotid glands, steatorrhoea and absence of trypsin in the duodenal juice. He rapidly lost oedema when given a sodium-free diet. $\mathrm{He}$ had a pituitary tumour, which was presumed to be the cause of the trouble.

Mussio-Fournier, Castiglioni and Anido (1934) described a 38-year-old patient with diarrhoea, oedema and hypoproteinaemia. Johansen (1938) described a 16-year-old girl with oedema, a large abdomen, wasting and infantilism, with hypoproteinaemia (total serum proteins $3 \cdot 6 \mathrm{~g}$. per $100 \mathrm{ml}$., albumin $2 \cdot 1$ g., globulin $1 \cdot 1$ g.), hypocalcaemia (serum calcium $7.8 \mathrm{mg}$. per $100 \mathrm{ml}$.) and with normal liver and renal function tests. No fat balance tests were carried out on these two cases, but they could well have had chronic steatorrhoea.

Salomonsen (1945) described a 2-year-old girl with persistent oedema, diarrhoea, hypoproteinaemia and normal renal function. No fat balance was performed, though simple analysis did not show excess of fat in the stools.

Story and Sagild (1953) described a fatal case of 'Whipple's disease'-steatorrhoea, arthralgia, elevation of serum glycoproteins, and hypoproteinaemia, with foamy cells in the mesenteric lymph nodes and intestinal mucosa. Their patient had oedema, and the total serum proteins were $3.6 \mathrm{~g}$. per $100 \mathrm{ml}$. (albumin $2 \cdot 1$ g.).

There remain a variety of case reports of very chronic generalized oedema and hypoproteinaemia of obscure origin. In most of these cases liver function tests were carried out and found to be normal, but in none of them (except in the case of Homburger and Petermann, 1949) were fat balance studies carried out in order to exclude steatorrhoea. Homburger and Petermann described a remarkable family exhibiting what they termed 'familial idiopathic dysproteinaemia'. The syndrome included oedema of the legs, ulcers in the males, functional vascular changes in the females, alterations in the plasma proteins, congenital malformations of the thoracic cage and abnormality of occipital hair distribution, and a high incidence of stillbirths. In one case the plasma proteins were low in spite of a positive nitrogen balance.

Keith (1932) mentioned five cases of unexplained oedema aged 9 to 69 years. Serum protein estimations were carried out in one only, the total being $4.6 \mathrm{~g}$. per $100 \mathrm{ml}$. No other information was given.

Myers and Taylor (1933) described a man of 51 with generalized oedema of many years' duration, with a history of a six months' episode of oedema at the age of 4 years. The total serum proteins varied between 3.3 and $4.0 \mathrm{~g}$. per $100 \mathrm{ml}$. A high protein diet was without effect. The laevulose tolerance was slightly reduced, but other liver function tests were normal. The serum calcium was $7.9 \mathrm{mg}$. per $100 \mathrm{ml}$. The serum amino-acid content was above normal, namely, 6.51 to $8.41 \mathrm{mg}$. per $100 \mathrm{ml}$. He had achlorhydria, a positive nitrogen balance and no excess of nitrogen in the stools. The hypoproteinaemia was ascribed to defective synthesis of plasma proteins.

Grabfield, Driscoll and Gray (1934) described a 32-year-old woman with chronic oedema, with a high total serum protein $(8 \cdot 3 \mathrm{~g}$. per $100 \mathrm{ml}$.) but with low serum albumin $(1 \cdot 7$ g. to $3 \cdot 7$ g.). The nitrogen balance was positive. There was a pelvic mass which was thought to be irrelevant.

Cope and Goadby (1935) described a 20-year-old man with normal blood pressure, normal haemoglobin and renal function tests, but with total serum proteins of $4.6 \mathrm{~g}$. per $100 \mathrm{ml}$. (albumin $3.1 \mathrm{~g}$., globulin 1.5 per $100 \mathrm{ml}$.). The nitrogen balance was positive, and a high-protein diet had no effect. Oedema was still present a year after the onset.

Binger and Keith (1937a, b) described a 35-year-old woman with chronic oedema and hypoproteinaemia and reduction of serum albumin. The total serum proteins were $2.7 \mathrm{~g}$. per $100 \mathrm{ml}$. No fat balance studies were made.

Rytand (1942) described a 24-year-old woman with chronic hypoproteinaemia and oedema. The total serum proteins varied between 3.0 and $4.7 \mathrm{~g}$. per $100 \mathrm{ml}$., the albumin being 2.7 to $2.9 \mathrm{~g}$. per $100 \mathrm{ml}$. The oedema lasted for more than eight years. The nitrogen balance was positive. The liver function tests were normal. There was some eosinophilia and reticulocytosis. A high-protein diet and amino-acids by mouth had no effect.

Albright, Bartter and Forbes (1949) studied a 19-year-old man with generalized oedema of two years' duration. His total serum proteins were 4.0 g. per $100 \mathrm{ml}$. (albumin $2.6 \mathrm{~g}$.), and renal and liver function tests were normal. A liver biopsy 
showed no abnormality. He was not anaemic. His serum calcium was $7.0 \mathrm{mg}$. per $100 \mathrm{ml}$, and the phosphorus $3.5 \mathrm{mg}$. A careful study of the fate of albumin when injected intravenously showed that the defect lay in an increased rate of destruction rather than in a decreased rate of synthesis. None of the injected albumin was lost in the urine.

Bound and Hackett (1953) described an infant, aged 1 month, with hypoproteinaemia from birth, with a virtual absence of gamma globulin. There was intermittent amino-aciduria. His haemoglobin was $13 \mathrm{~g}$. per $100 \mathrm{ml}$.: serum proteins $4.0 \mathrm{~g}$. per $100 \mathrm{ml}$. (albumin $2.5 \mathrm{~g}$.): the serum bilirubin, alkaline phosphatase, thymol turbidity and cholesterol were normal. An amino-acid chromatogram showed excess of glycine and alanine, threonine and a trace of cystine. The serum amino-acid nitrogen was $8.6 \mathrm{mg}$. per $100 \mathrm{ml}$. He suffered from recurrent staphylococcal infections. It was thought that the reduction of gamma globulin was against the possibility of liver disease. There was a similar history in a sibling, whose total serum proteins were $3.0 \mathrm{~g}$. per $100 \mathrm{ml}$., and whose liver at necropsy showed extensive fatty degeneration with a portal cellular reaction.

Below are case histories of two children who were under our care in the Children's Hospital, Sheffield.

\section{Case Reports}

Case 1, R.P. This boy was admitted at the age of 5 years and 11 months with a history of oedema and listlessness of one meek's duration. He had attended school for the last 12 months without missing a single day. He had had a good mixed diet, and no previous illness of note. There was no relevant family history.

He was a pale boy with ascites and generalized oedema, including oedema of the face, sacrum, genitals and lower limbs. There were a few petechiae on the abdomen, arms and legs-for which no explanation was found. Stools were normal on admission, but as a result of deliberately looking for it, steatorrhoea was found. Subsequently, three months after admission, the stools became loose and offensive. He became anaemic and was transfused several times with whole blood and plasma. In each case a good diuresis resulted, but fluid rapidly reaccumulated.

The urine was consistently normal chemically and microscopically. The serum proteins were reduced: the average of 22 serum protein estimations was $4.5 \mathrm{~g}$. per $100 \mathrm{ml}$.: the average of five serum albumin and globulin estimations was $2.6 \mathrm{~g}$. and $1.4 \mathrm{~g}$. per $100 \mathrm{ml}$. respectively. A nitrogen balance test was positive, but there was a high faecal nitrogen loss (at a time when he had diarrhoea). The erythrocyte sedimentation rate and the kidney and liver function tests were normal. There was no trypsin in a sample of duodenal juice, but the radiographs of the chest revealed no abnormality. A high-protein diet had

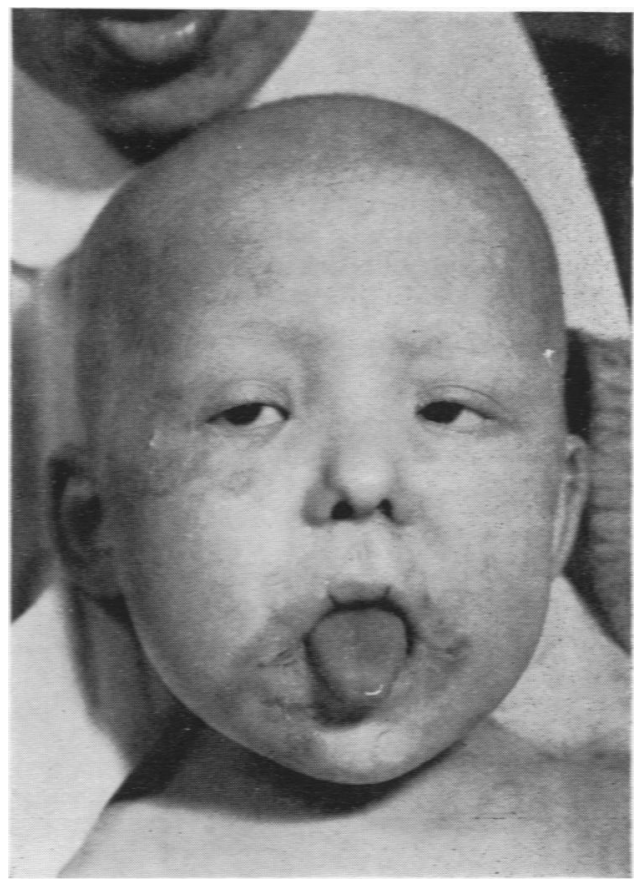

Fig. 1.-Photograph of Case 1 showing loss of hair, and signs of ariboflavinosis.

no effect, oedema persisted, and he was discharged in spite of it.

He was re-admitted four months later with gross oedema, an almost complete loss of hair, and severe ariboflavinosis, with redness and soreness at the inner and outer canthus of the eyes, around the nostrils, ears, angle of the mouth and the scrotum (Fig. 1). This responded rapidly to treatment with riboflavin, but subsequently relapsed. A month after admission he became jaundiced, and a diagnosis of serum hepatitis was made. The jaundice lasted for four months.

He was discharged with persistent oedema, but was re-admitted acutely ill at the age of 6 years and 11 months and died two weeks later.

At necropsy it was found that he had terminal bronchopneumonia, but no changes suggestive of cystic fibrosis of the pancreas. There was no abnormality of the salivary glands or of the mucous membrane of the respiratory tract. The pancreas appeared to be infiltrated with fat, and the lobules were widely spread, with fat globules scattered through the gland. The acini appeared to be collapsed and atrophic. The surface of the liver was slightly irregular and it was firm on section. It showed intense fatty change and swelling of the parenchymal cells. The wall of the stomach and jejunum was thickened. In the intestinal tract there was an increased cellularity beneath the surface epithelium and in the villi. The proximal tubular cells of the kidney and the tissue of the loops was swollen and vacuolated. 
There was an abnormal number of large fat globules in the tubular cells.

Biochemical InVestigations. The urine was consistently normal on repeated examinations, except for the presence of bilirubin and urobilinogen during the attack of jaundice.

An Addis count gave 500,000 red blood cells per 24 hours and 180,000 white blood cells per 24 hours.

The blood urea level was $15-30 \mathrm{mg}$. per $100 \mathrm{ml}$. (repeated estimations). The urea clearance test, hippuric acid test, and galactose tolerance test were all normal. A thymol turbidity test before jaundice gave a result of 1 unit. The Takata-Ara test was negative. The serum alkaline phosphatase level before jaundice was 5-11 King-Armstrong units.

The bilirubin level during jaundice was $2 \cdot 7 \cdot 4 \cdot 3 \mathrm{mg}$. per $100 \mathrm{ml}$, chlorides (as $\mathrm{NaCl}$ ) $635 \mathrm{mg}$. per $100 \mathrm{ml}$., cholesterol $120 \mathrm{mg}$. per $100 \mathrm{ml}$., proteins (total) 3.3$4 \cdot 2 \mathrm{~g}$. per $100 \mathrm{ml}$. (albumin $1 \cdot 8-3 \cdot 5 \mathrm{~g}$. per $100 \mathrm{ml}$., globulin 0.6-2.1 g. per $100 \mathrm{ml}$.).

Fractionation and electrophoresis (Professor Nicholas Martin), when the total serum proteins were $4 \cdot 2 \mathrm{~g}$. per $100 \mathrm{ml}$., showed a moderate increase of beta globulin and a slight increase of gamma globulin.

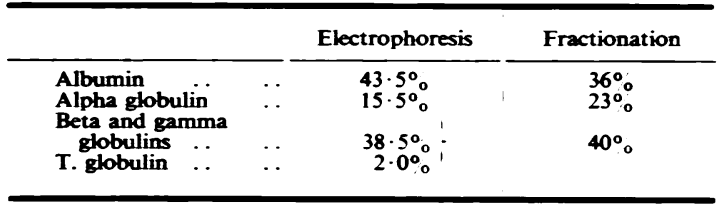

A nitrogen balance was positive.

Total intake (6 days) .

$\begin{array}{llllrl}\text { al intake (6 days) } & \ldots & \ldots & \ldots & 45.7 & \mathrm{~g} . \\ \text { Output in urine } & \ldots & \ldots & \ldots & 5.3 & \mathrm{~g} \\ \text { Output in stools } & \ldots & \ldots & \ldots & 22.0 & \mathrm{~g} \\ \text { Retention } & . . & \ldots & \ldots & \ldots & 18.4 \mathrm{~g} .\end{array}$

No trypsin was found in the duodenal juice. An amylase estimation showed that $6.5 \mathrm{~g}$. dextrose was liberated per $100 \mathrm{ml}$. (upper limit of normal).

The erythrocyte sedimentation rate on admission was $6 \mathrm{~mm}$. per hour.

The haemoglobin on admission was $8.9 \mathrm{~g}$. per $100 \mathrm{ml}$., red blood cells 3,000,000 per $\mathrm{ml}$. P.C.V. $37 \mathrm{ml}$., M.C.V 116 , halometer reading 6, M.C.H. $27 \cdot 5$, and M.C.H.C. 23.8. Prothrombin time was normal. The capillary fragility test (Wintrobe) was normal.

The Wassermann reaction was negative.

Tuberculin tests were negative.

Blood pyruvic acid was 0.95 mg. per $100 \mathrm{ml}$.

An E.C.G. was normal, as also was a radiograph of the chest.

The stools two months after admission were semi-solid, greasy, and contained $\mathbf{5 0}$ fat droplets per high power field, fairly large numbers of fatty acid crystals, a few extracellular starch granules and many fragments of undigested vegetable matter. The stools continued to show excess of fat, but no fat balance was performed.

The oedema fluid (peritoneal) was analysed as follows:

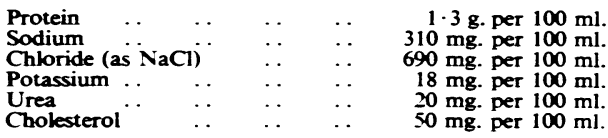

Case 2, D.C. This boy was admitted to a surgical ward at the age of 2 years on account of oedema of the legs for two weeks without any other symptoms. Till then he had been perfectly well, and had had no previous illnesses of note. There was no relevant family history. The boy had had a good mixed diet and weighed $27 \mathrm{lb}$.

He had pitting oedema of the lower limbs, genitals and sacrum. The oedema was more marked in the right leg than in the left. The abdomen was slightly protuberant, but there was no sign of free fluid. The blood pressure was normal $(80 / 45 \mathrm{~mm} . \mathrm{Hg})$, and there were no other abnormal physical signs.

Laboratory investigations showed that the urine was consistently normal. He had hypoproteinaemia, the average of 27 readings for the total serum proteins being $3.6 \mathrm{~g}$. per $100 \mathrm{ml}$. The average figures for the serum albumin and serum globulin were $2.0 \mathrm{~g}$. and $1.5 \mathrm{~g}$. per $100 \mathrm{ml}$. respectively. The erythrocyte sedimentation rate was normal, there was no anaemia, and the kidney and liver function tests were normal. The nitrogen balance was positive. Stools were repeatedly examined by the naked eye, and microscopic examination for excess of fat showed no excess of fat globules, but unfortunately as a result of undue reliance on these findings for excluding steatorrhoea, no fat balance was performed at this time.

The oedema persisted, and he was discharged on a high-protein diet with a diagnosis of hypoproteinaemia of unknown cause. The high-protein diet made no apparent difference, the oedema being unchanged. $\mathrm{He}$ was re-admitted at the age of 3 years 2 months, 3 years 10 months and $4 \frac{1}{2}$ years for cellulitis of a lower limb.c which in each case responded promptly to antibiotic treatment. In the last of these spells in hospital (at the age of $4 \frac{1}{2}$ years), a fat balance test was performed in order to exclude steatorrhoea, though the stools had remained normal macroscopically and microscopically. Definite steatorrhoea was demonstrated, and subsequently some stools were found to be pale and bulky, but no diarrhoea or looseness occurred. A gluten-free diet was given for four months, without any effect on the oedema or serum proteins, and it was discontinued.

Bile salt ('bilron') in a dose of $0.6 \mathrm{~g}$. three times a day before food had no effect on the serum proteins. He was then given five plasma transfusions, totalling $2,000 \mathrm{ml}$., and the serum proteins were thereby restored to normal and the cedema dispersed, but in a few days the serum protein had returned to the previous figure, the oedema recurring.

The child has now attended school regularly for nine months (present age 5 years 9 months), though slight oedema has persisted. His weight is $54 \mathrm{lb}$.

Biochemical Investigations. At the age of 2 the urine specific gravity was up to 1,029: the urine was consistently normal chemically and microscopically. The urea (single estimation) concentration was $1.05 \mathrm{~g} .{ }^{\circ} \circ$, amino-acid nitrogen $90 \mathrm{mg}$. ${ }_{0}$. An amino-acid chromatogram was normal, as also was a concentration test.

The stools were normal macroscopically, and microscopically showed less than 1 fat globule per high power 
field. Tryptic activity was seen up to a dilution of 1 in 640.

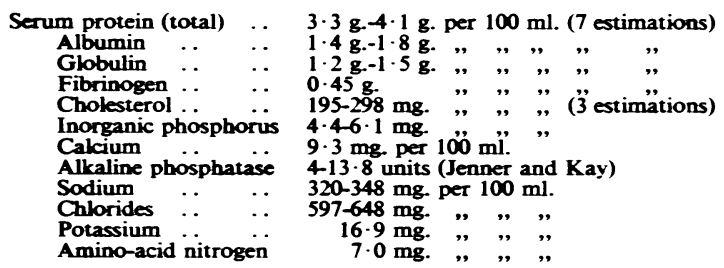

The blood urea level was 20-28 mg. per $100 \mathrm{ml}$. (three estimations). Thymol turbidity was less than 1 unit. The erythrocyte sedimentation rate was 3-11 mm. per hour (micro.), the haemoglobin $15 \cdot 1 \mathrm{~g}$. per $100 \mathrm{ml}$., the M.C.H.C. 33·5, and R.B.C. $4,000,000$ per c.mm.

A nitrogen balance was positive.

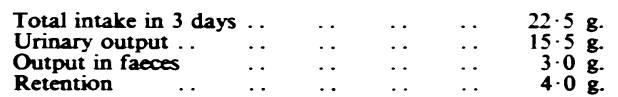

Between the ages of $4 \frac{1}{2}$ and $5 \frac{1}{2}$ years fat balances gave the following results: (i) $74 \%$ retention of total intake of 195 g. (3 days), (ii) $85 \%$ retention, (iii) $86 \%$ retention.

Nitrogen balances were positive as follows:

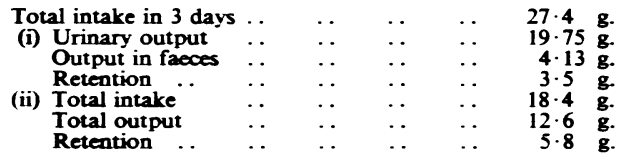

An amino-acid nitrogen curve after taking $5 \mathrm{~g}$. gelatin, $27 \mathrm{~g}$. 'casilan', juice of one orange and sugar gave:

\begin{tabular}{|c|c|c|c|c|c|c|c|}
\hline Fasting level & $\cdots$ & & & $4 \cdot 5 r$ & ng. & 100 & $\mathrm{ml}$. \\
\hline hour & 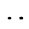 & * & & $5 \cdot 3$ & ", & $"$ & ," \\
\hline$"$ & . & & . & & ", & ", & $"$ \\
\hline 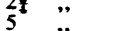 & - & -. & $\cdots$ & $\begin{array}{l}5.6 \\
5.6\end{array}$ & $"$ & ", & $"$ \\
\hline ", & $\cdots$ & $\cdots$ & $\cdots$ & & & & "’ \\
\hline
\end{tabular}

Amino-acid chromatograms (Dr. Bickel) showed (i) faint traces of glycine, alanine, glutamine and cystine; (ii) only traces of cystine; (iii) normal excretion of glycine, alanine, glutamine, histidine; (iv) excretion of cystine marked, but within normal limits, and excretion of glycine, serine, alanine, glutamine and glutamic acid normal or perhaps a little low.

Electrophoresis (Professor Nicholas Martin) showed a negligible amount of gamma globulin.

Bromsulphthalein excretion was normal: at 5 minutes $39 \%$ dye was excreted and at 30 minutes nil.

A glucose tolerance curve was normal.

Serum proteins (g. per $100 \mathrm{ml}$.) were analysed as follows:

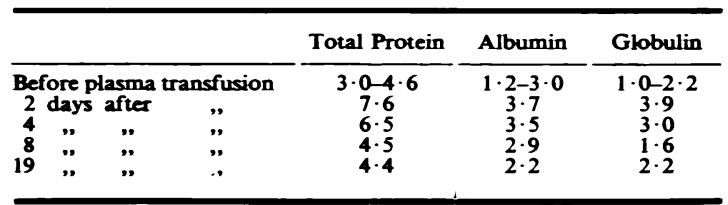

Serum amino-acids (mg.) were estimated by Dr. Bickel as follows:

\begin{tabular}{|c|c|c|c|c|}
\hline Amino-acid & & $\begin{array}{l}\text { Patient's } \\
\text { Level }\end{array}$ & $\begin{array}{l}\text { Normal Level } \\
\text { (Krebs, 1950) }\end{array}$ & S.D. \\
\hline $\begin{array}{l}\text { Phenylalanine } \\
\text { Tyrosine } \quad \text {. } \\
\text { Valine } \\
\text { Arginine } \quad \text {. }\end{array}$ & $\begin{array}{l}\cdots \\
\cdots \\
\cdots\end{array}$ & $\begin{array}{l}1 \cdot 15 \\
0 \cdot 7 \\
2 \cdot 6 \\
2 \cdot 4\end{array}$ & $\begin{array}{l}1 \cdot 38 \\
1 \cdot 48 \\
2 \cdot 83 \\
2 \cdot 34\end{array}$ & $\begin{array}{l}\mathbf{0} \cdot \mathbf{3 2} \\
\mathbf{0} \cdot \mathbf{3 7} \\
\mathbf{0} \cdot \mathbf{3 4} \\
\mathbf{0} \cdot \mathbf{7 0}\end{array}$ \\
\hline
\end{tabular}

Estimation of the total serum lipoids gave $555 \mathrm{mg}$. per $100 \mathrm{ml}$.

$\begin{array}{lll}\text { Serum sodium } & \ldots & \\ \text { Chlorides } & \ldots & \text {. } \\ \text { Potassium } & \ldots & \text {. } \\ \text { Cholesterol } & \text {. } & \text {. } \\ \text { Alkaline phosphatase } \\ \text { Phosphorus } & \ldots & \text {. } \\ \text { Cakcium } & \ldots & \text {. }\end{array}$

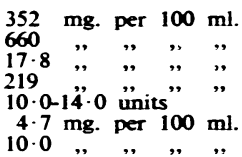

Thymol turbidity was less than 1 .

The blood urea level was $15 \mathrm{mg}$. per $100 \mathrm{ml}$.

The erythrocyte sedimentation rate was $3 \mathrm{~mm}$.

Haemoglobin was $14 \cdot 5-14 \cdot 8$ g. per $100 \mathrm{ml}$., P.C.V. 45\%, M.C.H.C. $33 \cdot 5 \%$.

The stools were microscopically normal and showed tryptic activity to a dilution of 1 in $\mathbf{3 2 0}$.

Duodenal juice showed tryptic activity to a dilution of 1 in 320, and amylase to 1 in 80 .

A radiograph of a wrist was normal, and a flocculating radiograph for intestinal pattern was also normal.

\section{Discussion}

A review of the literature gives a clear indication that at least some cases of chronic obscure oedema are associated with disease of the liver or pancreas, and with a defect of protein metabolism. It was certainly true that in all the cases in which nitrogen balances were performed the balance was positive, and in all the cases in which a high-protein diet was given it was of no avail.

We assumed that in both the children we have described the oedema was due to hypoproteinaemia, and particularly to the reduction of serum albumin, but the cause of the hypoproteinaemia was not clear. The protein intake in both appeared to have been normal before symptoms developed, and a highprotein diet in hospital did not appear to benefit them. In neither case had there been any history of diarrhoea, and naked-eye and microscopic examination of the stools was in both cases normal on admission. Steatorrhoea was found only as a result of specific investigation by means of fat balance tests, and we feel as a result of this experience that no investigation of obscure oedema is complete unless fat balance tests are performed. Diarrhoea did develop in one case (R.P.) after admission and later ariboflavinosis developed as a result, but at least in the early part of his illness it seemed unlikely, in 
the absence of diarrhoea, that the hypoproteinaemia was merely due to defective absorption of protein.

The level of certain amino-acids in the serum was low in one case, but electrophoretic analysis threw little light on the problem, except that the virtual absence of gamma globulin in one case (D.C.) helped to explain the recurrent attacks of cellulitis. We concluded that we did not know the cause of the hypoproteinaemia in these children.

The common cause of steatorrhoea in children is either coeliac disease or cystic fibrosis of the pancreas, but we felt in both cases that the cause of the steatorrhoea lay in some other condition. The necropsy findings in one case (R.P.) corresponded with those described by Lumb and Beautyman (1952) under the term 'hypoplasia of the exocrine tissue of the pancreas'. The second case (D.C.) differed from coeliac disease in the history and clinical findings, the lack of response to a gluten-free diet, and the absence of the characteristic radiological picture. Cystic fibrosis of the pancreas was virtually excluded by the finding of a normal quantity of trypsin in the duodenal juice, and the absence of lung complications. The cause of the steatorrhoea was therefore unknown.

The development of acute ariboflavinosis in R.P. was of particular interest.

\section{Summary}

After a review of the literature, two cases of obscure generalized oedema with hypoproteinaemia and steatorrhoea are described. One child died, and was found to have fatty infiltration of the pancreas and atrophic acini, without cystic fibrosis. The other child does not appear to have either cystic fibrosis of the pancreas or coeliac disease. The cause of the hypoproteinaemia was not determined.

We wish to thank Professor H. A. Krebs, F.R.S., for his helpful advice in the study of these cases and for reading through this paper. We also wish to thank Dr. H. Bickel for the amino-acid chromatograms, and Professor Nicholas Martin for the electrophoretic analyses. We are indebted to Dr. J. L. Emery for the post-mortem findings in one case.
REFERENCES

Albright, F., Bartter, F. C. and Forbes, A. P. (1949). Trans. Ass. Amer. Phys., 62, 204

Binger, M. W. and Keith, N. M. (1937a). J. Amer. med. Ass., 109, 1. Bo, (1937b). Proc. Mayo Clin., 12, 5 .

Bound, J. P. and Hackett, W. R. (1953). Archives of Disease in Childhood, 28, 104.

Cope, C. L. and Goadby, H. K. (1935). Lancet, 1, 1038.

Grabfield, G. P. Driscoll, M. and Gray, M. G. (1934). Arch. intern. Med., 54, 764.

Hantelmann, W. (1931). Virchows. Arch. path. Anat., 282, 630.

Homburger, F. and Petermann, M. L. (1949). Blood, 4, 1085.

Johansen, A. H. (1938). Acta path. microbiol. scand., Suppl. 37, p. 272.

Jones, G. G. (1949). Lancet, 1, 651

Jonsson. B. J. and Lagercrantz V. (1950). Acta paediat., Uppsala, $39,165$.

Jungmann, P. (1922). Klin. Wschr., 1, 1546.

Keith, N. M. (1932). J. clin. Invest., 11, 832

Lumb, G. and Beautyman, W. (1952). J. Path. Bact., 64, 679.

Melnick, D. and Cowgill, G. R. (1937). Yale J. Biol. Med., 10, 49.

Mussio-Foumier, J. C. Castiglioni, C. A. and Anido, J. B. (1934). Rev. Neurol., 41(1), 756, quoted by Cope and Goadby (1935).

Myers, W. K. and Tayior, F. H. L. (1933). J. Amer. med. Ass., 101, 198.

Edegärd. A. (1948). Nord. Med., 40, 2003.

Rytand, D. A. (1942). Arch. intern. Med., 69, 251

Salomonsen, L. (1945). Nord. Med., 25, 727.

Salvesen, H. A and 3 - J. (1937). Acta med. scand., 93, 228.

Salvesen, $H$. A. and 3-e J. (1937). Acta med. scand., 93, 228.

Schick, B. and Groenbaum, J. W. (1945). J. Pediat., 27, 241.

Thompson, W. H., Ziegler M. and McQuarrie, I. (1932). Amer. J. Dis. Child., 44, 650 . McQuarrie, I. and Bell, E. T. (1936). J. Pediat., 9, 604.

Warfield, L. M. (1936). Wis. med. J., 35, 95.

The references for the biochemical methods used are as follows:

1. Differential serum proteins: Wu, H. (1922). J. biol. Chem., 51, 33.

2. Serum lipoids:

Radwin, L. S., Michelson, J. P., Melnick, J. and Gottfried, S.ర (1940). Amer. J. Dis. Child., 60, 1120

3. Serum cholesterol:

Sackett, G. E. (1925). J. biol. Chem., 64, 203.

4. Serum chiorides:

Patterson, J. (1928). Biochem. J., 22, 758

5. Urea estimations in blood and urine:

King, E. J. (1946). Micro-analysis in Medical Biochemistry. London.

6. Sodium and potassium estimated by flame photometry using photometer of Evans Electroselenium Ltd.

7. Blood amino acids:

Microbiological assay. Schreier, $K$. and Plückthun, $H$. (1950). Biochem. Z., 320, 447.

Glutamine and Glutamic acid: Krebs, H. A. (1948). Biochem. J., 43, 51 .

8. Urine amino acids:

Consden, R. Gordon A. H. and Martin, A. J. P. (1944). Biochem. $j$. . 38, 224

Biochem. J., 38, 224.
Dent, C. E. (1947). Biochem. J., 41, 240.

9. Urine protein: Meztrezat 's turbimetric method:

Harrison, G. A. (1947). Chemical Methods in Clinical Medicine, 3rd ed. London.

10. Urine specific gravity:

Dogramaci, J. (1947). J. Pediat., 30, 672.

11. Nitrogen estimations:

Micro-Kjeldahl method followed by distillation or nesslerization:

Peters, J. P. and Van Slyke, D. D. (1932). Quantitative Clinical Chemistry, Vol. II. London.

12. Fat estimations:

Modifications of method of Cammidge, P. J. (1914). The Faeces of Children and Adults. Bristol. 